\title{
Organic enrichment by macrophyte detritus, and abundance patterns of megafaunal populations in submarine canyons
}

\author{
E. W. Vetter ${ }^{1, *}$, P. K. Dayton ${ }^{2}$ \\ ${ }^{1}$ Hawaii Pacific University, 45-045 Kamehameha Highway, Kaneohe, Hawaii 96744, USA \\ ${ }^{2}$ Scripps Institution of Oceanography, UCSD 0201, 9500 Gilman Dr., La Jolla, California 92093-0201, USA
}

\begin{abstract}
Submarine canyons can provide large quantities of food in aggregated form on the deepsea floor by acting as conduits for marine macrophyte production produced in the intertidal and shallow subtidal zone. Longshore transport delivers substantial quantities of macrophyte detritus from surfgrass Phyllospadix torreyi, kelps Macrocystis pyrifera and Egregia menziesii, and other macroalgae to the heads of Scripps and La Jolla Submarine Canyons. Strong tidal and gravity currents distribute this material throughout much of the canyon system, where it is utilized as food and habitat by benthic fauna. Video data taken from remotely operated vehicles and submarines were used to evaluate differences in detrital cover and megafaunal abundance in the canyons, and at nearby reference stations. Within the canyons dense mats of detritus were common down to $550 \mathrm{~m}$, and $M$. pyrifera holdfasts were observed at 700 and $900 \mathrm{~m}$. Virtually no drift material was observed out of the canyons. Comparisons of megafaunal invertebrates in and out of the canyons revealed generally higher densities at noncanyon sites due to large numbers of urchins. Species richness of all megafauna and abundance of nonurchin megafauna were greater in the canyons than out. It is likely that urchin abundance in canyons is reduced through disturbance by currents and detrital flows in the canyons. Species richness and abundance of fishes were greater in the canyons at all depths for which comparative data were available $(100$ to $500 \mathrm{~m})$. From 150 to $200 \mathrm{~m}$ in Scripps Canyon, juvenile Pacific hake Merluccius productus were so abundant at times that their bodies obscured visibility. Turbot Pleuronichthys sp. and zoarcids Lycodes pacifica were also abundant in Scripps Canyon from 100 to $300 \mathrm{~m}$. Data from this study support the hypotheses that macrophyte detritus covers large areas of the La Jolla and Scripps Canyon axis, and that megafaunal abundance is associated with detritus at both large and small spatial scales.
\end{abstract}

KEY WORDS: Submarine canyon - Detritus - Megafauna - Organic enrichment - Community - Physical disturbance $\cdot$ Surfgrass $\cdot$ Kelp

\section{INTRODUCTION}

Community composition and respiration in some regions of the sea floor are strongly influenced by food falls in the form of nekton carcasses (Stockton \& DeLaca 1982, Smith 1985, 1986, Vetter 1996), macrophyte detritus (Wolff 1976, 1979, Thrush 1986, Lawson et al. 1993, Vetter \& Dayton 1998), and pulsed inputs of phytodetritus (Billett et al. 1983, Lampitt 1985, Thiel et al. 1988/1989, Smith et al. 1992). Most studies

\footnotetext{
•E-mail: evetter@hpu.edu
}

of this issue have been carried out in the deep sea where a background of low productivity amplifies the effect of food falls, especially on local diversity (Grassle \& Morse-Porteous 1987). The greater productivity of waters overlying the continental shelf and slope, however, support a greater abundance and biomass of nekton and therefore a greater incidence of food falls. Regions near substantial marine macrophyte communities, or that receive detritus-rich outflows from estuaries, are probably most heavily impacted by food falls. Detritus with relatively low specific gravity, such as fine particulate and plant matter, will have greatest effect where physical condi- 
tions allow it to accumulate and persist long enough to be exploited by detritivores. On small scales, such conditions exist in the lee of rocks and other debris, in and around biogenic structures such as pits and mounds (VanBlaricom 1982, Thiel et al. 1988/1989), and on larger scales in depressions such as small basins, and submarine canyons and troughs (Josselyn et al. 1983, Okey 1993, Vetter 1995a, Harrold et al. 1998).

Submarine canyons receive macrophyte detritus and other bedload debris originally deposited on wide areas of the coastline by intercepting material transported along the shore by wave energy (Inman \& Frautschy 1965, Shepard \& Dill 1966, Inman \& Brush 1973). This is especially true for canyons with shallow heads; however, large accumulations of kelp detritus have also been reported from offshore canyons (BBA \& ROS 1986). Canyons located near macrophyte communities, such as forests of the giant kelp Macrocystis pyrifera, are likely to be highly organically enriched because of the high productivity of this species (Foster
\& Schiel 1985) and the large proportion of that production which is exported (Zobell 1959, 1971, Gerard 1976). Once in canyons, detritus is transported deeper by continuous processes, such as periodic resuspension by tidal flows, and by violent episodic events, such as slumps and turbidity currents (Shepard 1973, Inman et al. 1976, Gardner 1989). Organic aggregates channeled to the deep-sea through submarine canyons may provide habitat for fishes and increase their invertebrate prey populations through elevated benthic secondary production.

Suspension feeders may benefit from enhanced currents and behavior of their prey within canyons. Several studies have found higher than background abundances of plankton and micronekton in and around canyons (Koslow \& Ota 1981, Greene et al. 1988, Hecker et al. 1988, Cartes et al. 1993, MacquartMoulin \& Patriti 1993). This may result from concentration of these pelagic animals at the base of canyons as they migrate down during the day, or through aggregation around physical structures associated with the

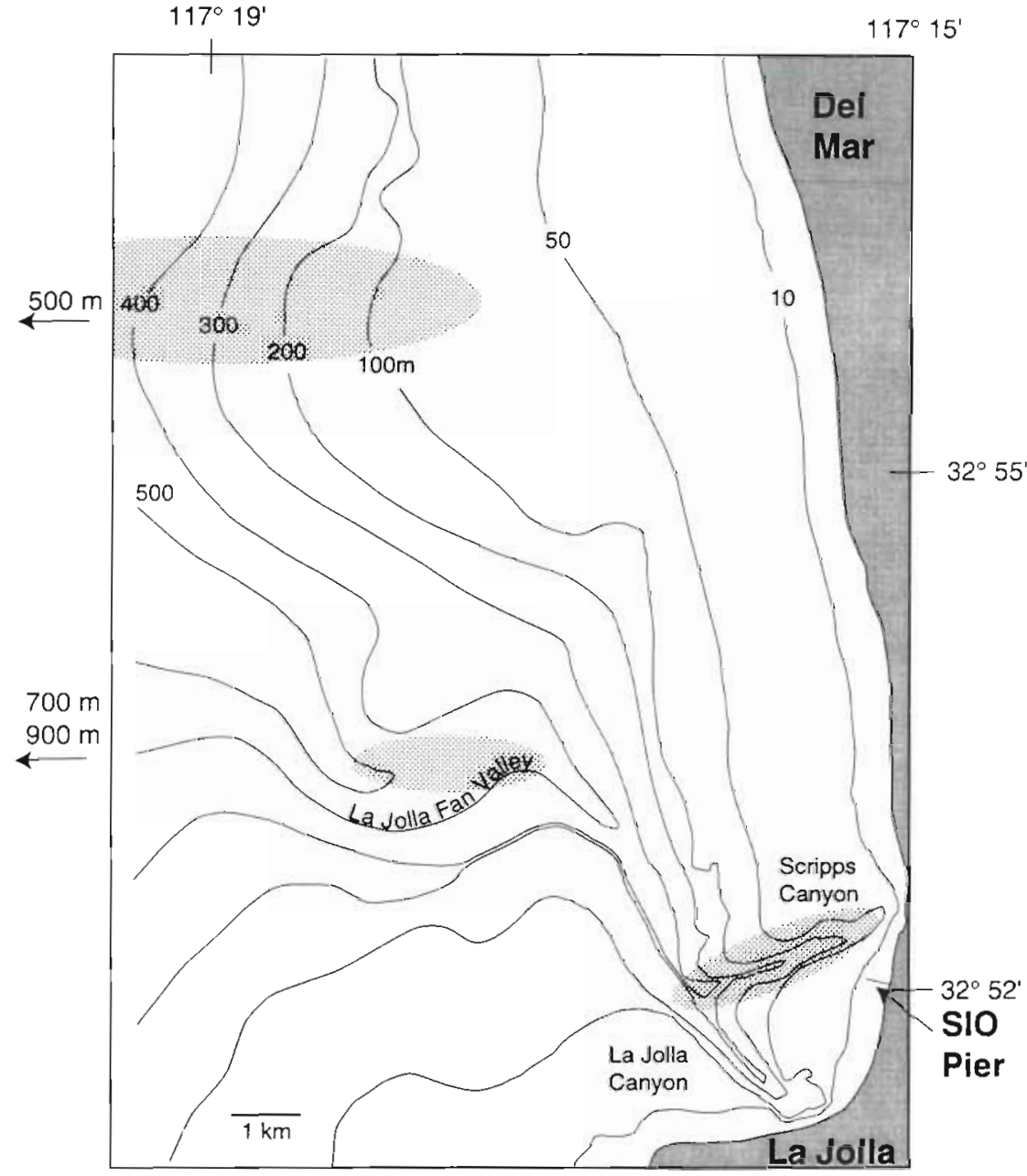

Fig. 1. Southern California coastline from Del Mar to Pt. La Jolla. Shaded regions show areas sampled. The Del Mar $500 \mathrm{~m}$ and La Jolla Canyon 700 and $900 \mathrm{~m}$ areas are not shown. The approximate location of Scripps Institution of Oceanography pier is are shown 
canyons. Even in the absence of increased density of plankton and other food items, suspension feeders probably benefit from enhanced currents commonly found in canyons (Shepard et al. 1979).

Studies of infaunal patterns in canyons have found both increased biomass or density (Gage et al. 1995) and decreased biomass or density (Houston \& Haedrich 1984, Maurer et al. 1994). Rowe et al. (1982) found that macrofaunal biomass was greater within the Hudson Canyon only at depths where the canyon was geologically inactive and was accumulating organicrich, fine-grained sediments. Scripps and La Jolla Canyons are active throughout their length, have course-grained sediments and yet still house increased density and biomass of macrofauna (Vetter \& Dayton 1998). Most studies of canyon megafauna have reported increased megafaunal density or biomass in canyons (Rowe 1971, Haedrich et al. 1975, 1980, Hecker et al. 1988, Cartes et al. 1994).

Large accumulations of detrital kelp Macrocystis pyrifera and Egregia menziesii and surfgrass Phyllospadix torreyi at the heads of Scripps and La Jolla Submarine Canyons were found to support enormous populations of macrofaunal crustaceans, which in turn supported large numbers of fishes (Vetter 1995b). Detritus arrived at the heads of these canyons at all times of the year, while export of that material appeared to be largely confined to periods of strong wave action, primarily during winter and spring storms (Vetter 1998). Those observations led us to hypothesize that large portions of the floor of La Jolla and Scripps Canyons are regularly covered with macrophyte detritus, and that megafaunal abundance is positively correlated with detritus and its associated macrofauna at large and small scales.

For the purposes of this study, detritus refers to large, identifiable pieces or entire plants of drift algae and surfgrass. Particulate detritus was abundant, but was not easily quantifiable except as parts of organic aggregates. Here, megafauna refers to animals large enough to be seen by eye on video, for the most part, animals larger than about $2 \mathrm{~cm}$.

\section{MATERIALS AND METHODS}

Video data were taken in July and August 1995 from submersibles in Scripps and La Jolla submarine canyons $\left(32^{\circ} 52^{\prime}\right.$ to $32^{\circ} 54^{\prime} \mathrm{N}, 117^{\circ} 15^{\prime}$ to $\left.117^{\circ} 19^{\prime} \mathrm{W}\right)$, and a nearby control area $\left(32^{\circ} 49^{\prime}\right.$ to $32^{\circ} 51^{\prime} \mathrm{N}, 117^{\circ} 21^{\prime}$ to $117^{\circ} 23^{\prime} \mathrm{W}$ ) at depths between 100 and $550 \mathrm{~m}$. Data were also collected from La Jolla Canyon at $700 \mathrm{~m}$ $\left(32^{\circ} 55^{\prime} \mathrm{N}, 117^{\circ} 26^{\prime} \mathrm{W}\right)$ and $900 \mathrm{~m}\left(32^{\circ} 51^{\prime} \mathrm{N}, 117^{\circ} 34^{\prime} \mathrm{W}\right)$ (Fig. 1, Table 1). La Jolla Canyon follows a sinuous path from its head, which is visible at a depth of $20 \mathrm{~m}$, to the San Diego Trough, $39 \mathrm{~km}$ to the west at a depth of $900 \mathrm{~m}$. Scripps Canyon branches off La Jolla Canyon at a depth of $290 \mathrm{~m}$ and continues as a straight rock gorge for about $2.7 \mathrm{~km}$ inshore to a depth of $15 \mathrm{~m}$.

Strong currents (Shepard et al. 1979) and a source of beach sand at the head of the canyons result in wellsorted sandy sediments in the canyons to a depth of at least $700 \mathrm{~m}$ (Vetter \& Dayton 1998). Between 700 and $900 \mathrm{~m}$ canyon sediments transform into poorly sorted mud with a high silt content. Organic carbon in canyon sediments was significantly lower than in non-canyon sediments at 300 and $500 \mathrm{~m}$ (Vetter \& Dayton 1998). This may be due to strong canyon currents that winnow away much of the fine particulate matter, which includes much of the organic material.

Relative abundances of megafaunal invertebrates and fishes were estimated from video taken by a starboard-directed Hi-8 camera system mounted on the submersible 'Delta' (100 to $300 \mathrm{~m}$ depth range), and from a forward-directed $\mathrm{Hi}-8$ camera on the advanced tethered vehicle (ATV, a remotely operated vehicle, used for depths from 310 to $900 \mathrm{~m}$ ). Transect data were collected on 32 dives. Transects at the control area were run along isobaths; within La Jolla Canyon they were run using a serpentine down-canyon pattern. The narrow floor of Scripps Canyon forced us to run transects straight up and down the gorge. Transects were run along both sides and down the center of the Scripps Canyon axis.

Megafaunal invertebrates and fishes in the lower $2 / 3$ of each video frame were counted. This constrained our sampled area to within about 0.8 to $2 \mathrm{~m}$ of the submersibles. The upper $1 / 3$ of the frame usually recorded a much greater area of the sea floor than the lower $2 / 3$. and could not be reliably sampled. Frames were advanced by selecting a feature on the sea floor at the leading edge of the monitor and advancing the tape until it disappeared from view at the trailing edge of

Table 1. Number of video frames used for relative abundance estimates by depth and location (DM: Del Mar, non-canyon; CYN: canyon, 100 to 280 Scripps Canyon, 310 to 700 La Jolla (anyon)

\begin{tabular}{|lcc|}
\hline Station & Depth sampled $(\mathrm{m})$ & No. of frames \\
\hline DM 100 & $90-120$ & 595 \\
DM 200 & $190-215$ & 290 \\
DM 300 & $280-310$ & 385 \\
DM 500 & $495-510$ & 820 \\
CYN 100 & $90-125$ & 307 \\
CYN 200 & $160-230$ & 121 \\
CYN 280 & $260-290$ & 80 \\
CYN 310 & $300-320$ & 59 \\
CYN 500 & $490-550$ & 993 \\
CYN 700 & $695-705$ & 280 \\
\hline
\end{tabular}


the monitor. All of the video in which the vehicles were swimming level and just skimming the bottom was used. This criteria constrained the area sampled by each frame and disqualified more than half of the video, It also prevented us from sampling from video when the vehicles were stationary. Frame area llower $2 / 3$ of monitor) varied between about 0.8 to $1.5 \mathrm{~m}^{2}$ with the Delta's video system, and from about 1.5 to $3 \mathrm{~m}^{2}$ with the ATV's camera. Cross depth and platform megafaunal comparisons were not made. For example. data collected from the canyon at or near $100 \mathrm{~m}$ with Delta were only compared with data taken at the reference station at the same depth also using Delta. The relatively low spatial variability between frames and the large number of frames evaluated (Table 1) minimized errors in abundance estimation. On occasion the vehicles were stopped so that close-up video of animals and detritus could be taken to help with identification.

Percent cover of organic aggregates within Scripps and La Jolla Submarine Canyons was quantified over depths from 20 to $900 \mathrm{~m}$, and at the non-canyon control station from 100 to $500 \mathrm{~m}$. At scuba depths ( 20 to $65 \mathrm{~m}$ ) percent cover of detrital patches was estimated by laying a $50 \mathrm{~m}$ tape measure along the canyon axis and recording the width of the canyon, detrital patches and clear spaces every $3 \mathrm{~m}$. Percent cover of detritus below $60 \mathrm{~m}$ was estimated from video data. For video analysis of detrital cover a uniform grid of 100 dots was placed on the lower $2 / 3$ of the monitor. Percent cover per frame was recorded as the number of dots which fell on part of an organic aggregate. Species composition of the detritus could not be reliably determined from the video.

Statistical comparisons (ANOVA) were made with the Macintosh statistical package SYSTAT (V. 5.2.1, SPSS Inc., Chicago, IL, USA).

\section{RESULTS}

Detritus cover within the canyon ranged from 90 to $100 \%$ between 30 and $65 \mathrm{~m}$, to $5 \%$ at $500 \mathrm{~m}$, and was sparse at $700(0.2 \%)$ and $900 \mathrm{~m}(<0.1 \%)$ (Fig. 2). Estimates of cover at $500 \mathrm{~m}$ were likely biased downward by data taken from the sloping substrate near the base of the canyon walls rather than the canyon floor. Along the non-canyon transects off of Del Mar, the only detritus observed were 2 freshly deposited Macrocystis pyrifera fronds at $100 \mathrm{~m}$. Within the canyon $M$. pyrifera debris was found at all depths (to $900 \mathrm{~m}$ ), but at $500 \mathrm{~m}$ detrital patches were strongly dominated by surfgrass (Phyllospadix spp.). Most of the detritus in the canyon was aggregated into dense mats which commonly exceeded $10 \mathrm{~cm}$ in thickness and could easily conceal megafaunal fishes and invertebrates.

A small tree branch (about $1 \mathrm{~m}$ long) found at $700 \mathrm{~m}$ within the canyon was inhabited by large numbers of snails (25 to 50) and amphipods (100 to $>300)$. A small $\log$ found at $500 \mathrm{~m}$ hosted at least 7 large crabs Glyptolithodes cristatipes which were grazing on what appeared to be filamentous bacteria extending out from the log. Close-up video revealed that the portion of the log behind the crabs had been scraped clean, and the rest of the log was covered with thin filaments of a white substance which gave it a furry appearance. The filaments looked much like the bacterium Beggiatoa $\mathrm{sp}$. which was identified from detritus collected at $50 \mathrm{~m}$ in the canyon (Vetter unpubl. data). At depths between 300 and $500 \mathrm{~m}$ patches of Phyllospadix spp. detritus were frequently observed with large aggregations $\left(100 \mathrm{~s}\right.$ to $1000 \mathrm{~s}$ over $\sim 10$ to $200 \mathrm{~cm}^{2}$ of detritus) of amphipods on the surface of the detrital aggregates.

Relative megafaunal abundance data cannot be compared across platforms because the video system on the ATV tended to sample a slightly larger area $\left(1.5\right.$ to $\left.3 \mathrm{~m}^{2}\right)$

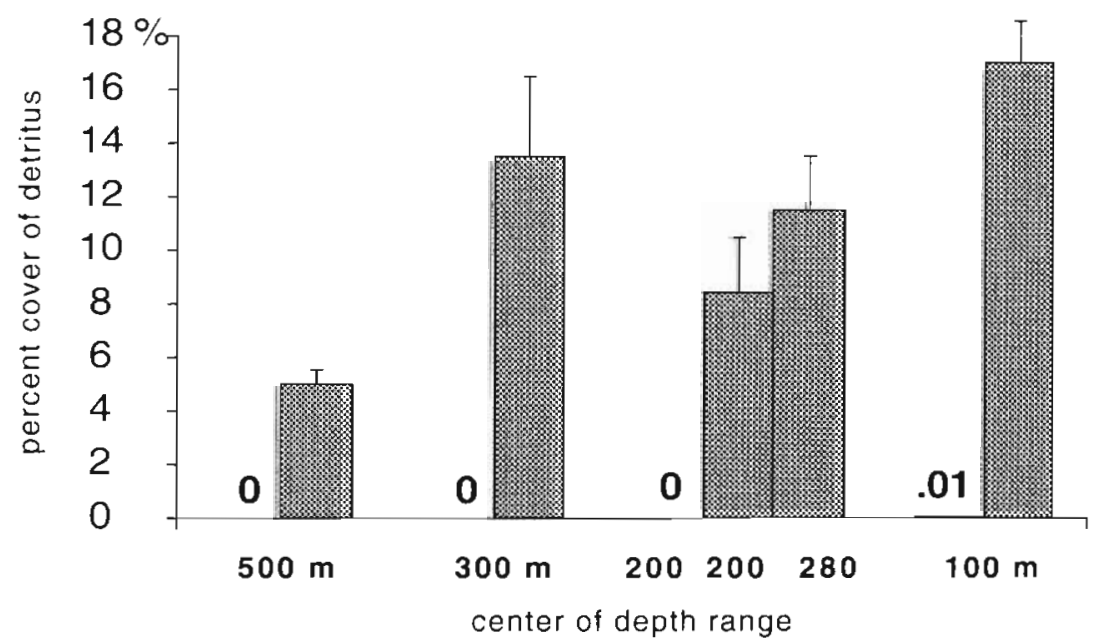

center of depth range
Fig. 2. Percent cover of detritus on the sea floor by depth and location. Columns represent canyon data and numbers noncanyon (Del Mar) data. Error bars are 1 standard error 
Table 2. Summary of ANOVA results comparing invertebrate megafaunal abundances between canyon and non-canyon sites. F-ratio and p-values in parentheses are for data excluding urchins

\begin{tabular}{|lrrcc|}
\hline & df & Mean square & $F$-ratio & $p$ \\
\hline $500 \mathrm{~m}$ & 1 & 209.8 & 26.78 & $<0.001$ \\
Error & 1888 & 7.9 & $(31.17)$ & $(<0.001)$ \\
$300 \mathrm{~m}$ & 1 & 0.3 & 0.13 & 0.722 \\
Error & 442 & 2.3 & $(89.77)$ & $(<0.001)$ \\
$200 \mathrm{~m}$ & 3 & 48.7 & 8.67 & $<0.001$ \\
Error & 670 & 5.6 & $(41.46)$ & $(<0.001)$ \\
$100 \mathrm{~m}$ & 1 & 52.7 & 16.19 & $<0.001$ \\
Error & 900 & 3.3 & $(11.51)$ & $(<0.002)$ \\
\hline
\end{tabular}

than the one on Delta $\left(0.8\right.$ to $\left.1.5 \mathrm{~m}^{2}\right)$. Likely differences in the measurement uncertainty associated with each vehicle would have also made direct comparisons inappropriate. Abundance of megafaunal invertebrates was significantly greater out of the canyon at 500 and $200 \mathrm{~m}$ (Table 2), there was no difference at $300 \mathrm{~m}$, and the difference was greater in the canyon at $100 \mathrm{~m}$ (Figs. $3 \& 4$, Table 2). At $500 \mathrm{~m}$ the non-canyon sites were dominated by the heart-urchin Brissopsis pacifica, but the regular urchin Allocentrotus fragilis, asteroids (mostly Mixoderma platyacanthum), and the holothurian Pannychia moseleyi were also common. The canyon differed by having relatively few $B$. pacifica, no A. fragilis, and the benthic siphonophore Dromalia alexandri (Tables $3 \& 4$ ) was common. At $300 \mathrm{~m}$, noncanyon transects were strongly dominated by $A$. fragilis with relatively few $B$. pacifica. The canyon was also dominated by $A$. fragilis (most within $1 \mathrm{~m}$ of the walls), and holothurians, benthic siphonophores and octopus were common (Table 3). Non-canyon sites at 200 and $300 \mathrm{~m}$ were similar in megafaunal composition. Within the canyon at $200 \mathrm{~m}$ the urchin Lytechinus pictus and large prawns appeared, Parastichopus californicus replaced Pannychia moseleyi, and the benthic siphonophores became less common. At $100 \mathrm{~m}$ Parastichopus californicus were observed at non-canyon sites and $A$. fragilis virtually disappeared from the canyon. When urchins are excluded from the analysis, megafaunal abundances are significantly greater in the canyons at all depths (Figs. $3 \& 4$, Table 2).

Megafaunal invertebrates were strongly associated with detrital aggregates at
$500 \mathrm{~m}$ in the canyon, averaging 2.7 individuals per frame where detritus covered more than $5 \%$ of the frame, and 1.6 in other frames (ANOVA, $p<0.001$ ). At $300 \mathrm{~m}$ the association of megafaunal invertebrates was even stronger, with a mean of 2.9 individuals in frames with detrital aggregates and 0.2 in frames without aggregates (ANOVA, $p<0.001$ ). In Scripps Canyon $(100$ to $290 \mathrm{~m})$ an average of 1.4 animals were observed in frames with detrital aggregates and 0.7 in frames without (ANOVA, $p=0.002$ ). Below $200 \mathrm{~m}$ some animals, especially the holothurian Pannychia moseleyi and the crab Glyptolithodes cristatipes, were common within the detrital mats and may have been severely under-counted. On several occasions when the ATV was stopped at detrital patches to collect samples, the wash from the propellers disturbed the detritus revealing crabs that had been completely obscured. Counts of $P$. moseleyi could have been improved if we had stopped at each detritus patch and carefully panned the camera to cover the portion of the patches within the transect area, but this would have violated our transect sampling protocol.

The pattern of increased megafaunal abundance near detrital aggregates held for fishes at $500 \mathrm{~m}(0.8 \mathrm{fish}$ frame $^{-1}$ near detritus, 0.3 away. ANOVA, $p<0.001$ ) but not at $300 \mathrm{~m}\left(0.6\right.$ fish frame $\mathrm{e}^{-1}$ near detritus, 0.3 away, ANOVA, $p=0.19$ ), and it was barely significant at depths

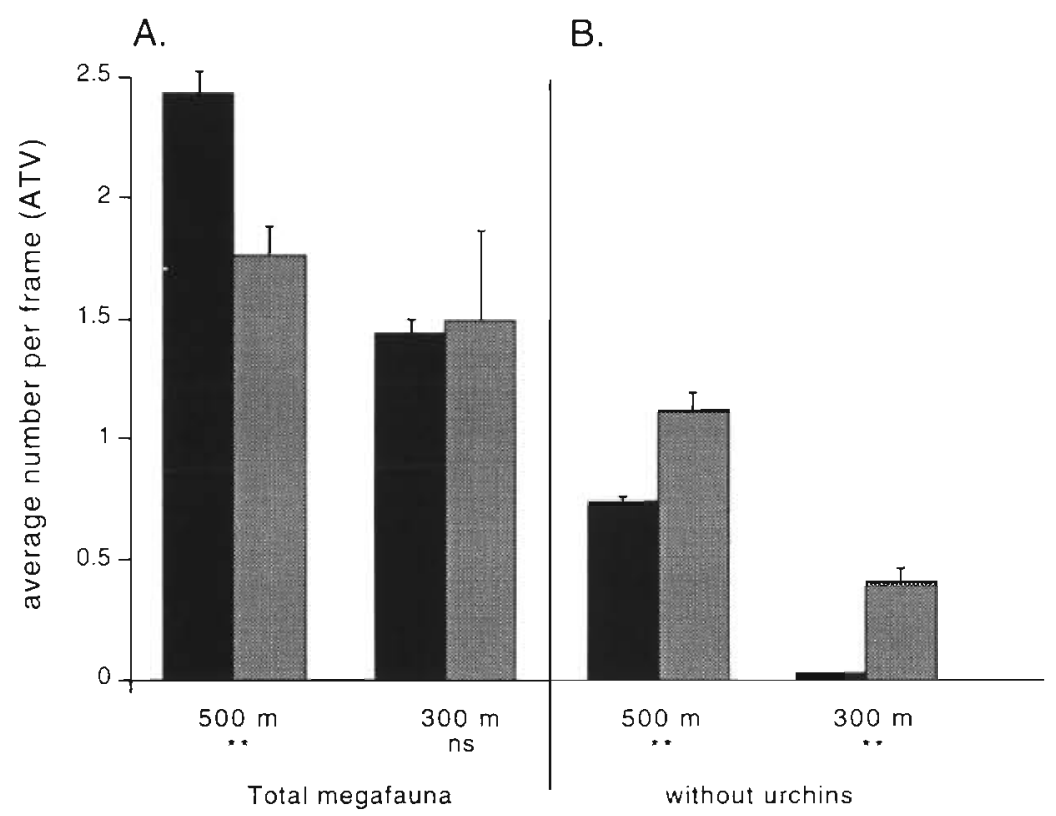

Fig. 3. Relative abundance of megafaunal invertebrates at 300 and $500 \mathrm{~m}$. Solid columns show non-canyon data and shaded columns data from canyon stations. (A) All invertebrate megafauna. (B) All invertebrate megafauna except for sea urchins. Video data from the advanced tethered vehicle (ATV), frame size approximately $2 \mathrm{~m}^{2}$ Error bars are 1 standard error. Asterisks indicate significant differences in megafaunal abundances within the given depth range, $" p<0.001, n s=$ not significant (ANOVA, Table 2 ) 


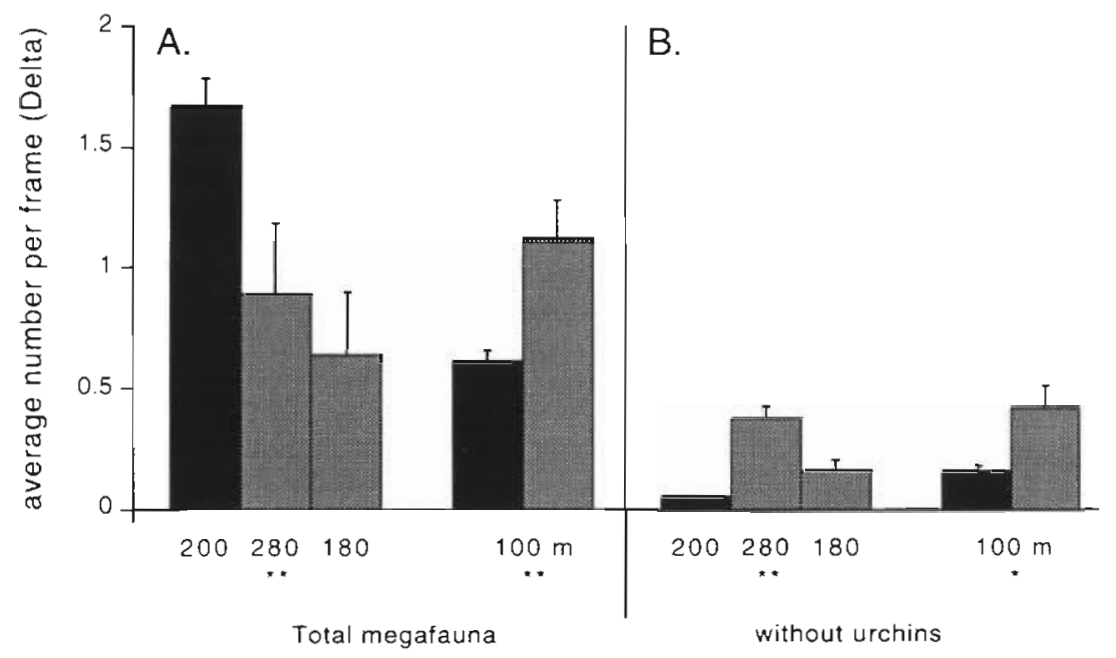

Fig. 4. Relative abundance of megafaunal invertebrates at 100 and $200 \mathrm{~m}$. Solid columns show non-canyon data and shaded columns data from canyon stations. (A) All invertebrate megafauna. (B) All invertebrate megafauna except for sea urchins. Video data from the submersible 'Delta', frame size approximately $1 \mathrm{~m}^{2}$. Error bars are 1 standard error. Asterisks indicate significant differences in megafaunal abundances within the given depth range, " $p<$ $0.002, \cdots p<0.001$ (ANOVA, Table 2)

Table 3. Relative abundance of fishes and invertebrate megafauna. Values are individuals per 100 frames (about 200 to $300 \mathrm{~m}^{2}$ ). Holothurians change from exclusively Parastichopus sp. at $100 \mathrm{~m}$ to exclusively Pannychia moseleyi at $500 \mathrm{~m}$. Zeros indicate an average density of $<0.2$ individuals per 100 frames

\begin{tabular}{|c|c|c|c|c|c|c|c|c|}
\hline \multirow{3}{*}{$\begin{array}{l}\text { Platform: } \\
\text { Location: } \\
\text { Depth: }\end{array}$} & \multicolumn{4}{|c|}{ ATV } & \multicolumn{4}{|c|}{ DELTA } \\
\hline & $\mathrm{DM}$ & CYN & DM & CYN & $D M$ & CYN & DM & CYN \\
\hline & 500 & 500 & 300 & 310 & 200 & 200 & 100 & 100 \\
\hline \multicolumn{9}{|l|}{ Invertebrates } \\
\hline Brissopsis pacifica & 170 & 9 & 13 & 0 & 24 & 0 & 5 & 0 \\
\hline Allocentrotus fragilis & 52 & 0 & 126 & 95 & 139 & 26 & 41 & 1 \\
\hline Lytechinus pictus & 0 & 0 & 0 & 0 & 1 & 24 & 0 & 28 \\
\hline Asteroids (spp.) & 46 & 43 & 0 & 0 & 0 & 0 & 4 & 0 \\
\hline Pannychia moseleyi & 17 & 43 & 0 & 15 & 0 & 0 & 0 & 0 \\
\hline Parastichopus sp. & 0 & 0 & 0 & 0 & 0 & 12 & 7 & 9 \\
\hline Dromalia alexandri & 0.1 & 16 & 1 & 12 & 1 & 1 & 0 & 0 \\
\hline Decapods (spp.) & 0 & 0 & 0 & 0 & 0 & 7 & 0 & 24 \\
\hline Octopus sp. & 0 & 0 & 0 & 5 & 0 & 2 & 0 & 0 \\
\hline \multicolumn{9}{|l|}{ Fishes } \\
\hline Juv. Merluccius productus, & 4 & 8 & 0 & 5 & 0.4 & 900 & 0 & 69 \\
\hline Adult $M$. productus, hake & 2 & 2 & 0.3 & 7 & 0 & 2 & 0 & 0 \\
\hline Sebastolobus sp., thornyhead & 0.2 & 5 & 3 & 0 & 0 & 0 & 0 & 0 \\
\hline Anoplopoma fimbria, sablefish & 6 & 11 & 2 & 12 & 0 & 0 & 0 & 0 \\
\hline Facciolella gilberti, witch eel & 0 & 5 & 0 & 0 & 0 & 0 & 0 & 0 \\
\hline Microstomus pacificus, sole & 0 & 48 & 4 & 0 & 0 & 0 & 0 & 0 \\
\hline Pleuronichthys sp., turbot & 0 & 0 & 0 & 0 & 0 & 118 & 4 & 208 \\
\hline Lycodes pacifica & 0 & 0 & 0 & 0 & 0 & 36 & 0 & 38 \\
\hline Scorpaena guttata & 0 & 0 & 0 & 0 & 0 & 0 & 0 & 3 \\
\hline
\end{tabular}

shallower than $300 \mathrm{~m}$ (Scripps Canyon, 5.7 fish frame $\mathrm{f}^{-1}$ near detritus, 3.8 away, ANOVA, $p=0.04$ ).

Canyon stations had more fish than non-canyon stations at all depths (Table 5, Fig. 5). Within La Jolla Canyon sole Microstomus pacificus were largely responsible for this difference at $500 \mathrm{~m}$, and relatively large numbers of sablefish Anoplopoma fimbria and hake Merluccius productus were important at $300 \mathrm{~m}$. Inshore of $300 \mathrm{~m}$ (in Scripps Canyon) the difference was even more pronounced, with large numbers of hake, turbot Pleuronichthys sp., and zoarcids Lycodes pacifica in the canyon (Table 3). From about 150 to $230 \mathrm{~m}$ juvenile hake were exceptionally abundant (often obscuring view of the bottom) within $2 \mathrm{~m}$ of the canyon floor. Dense aggregations of juvenile hake from 150 to $200 \mathrm{~m}$ prevented us from recording data in the regions where fishes were most abundant, severely biasing our estimates of fish abundance downward at those depths in the canyon (transect data were only recorded when the bottom was clearly visible). 
Table 4. Summary of ANOVA results comparing Dromalia alexandri abundance between canyon and non-canyon sites

\begin{tabular}{|lrrcc|}
\hline & df & Mean square & F-ratio & $\mathrm{p}$ \\
\hline $500 \mathrm{~m}$ & 1 & 12.09 & 106.34 & $<0.001$ \\
Error & 1888 & 0.11 & & \\
$300 \mathrm{~m}$ & 1 & 0.57 & 19.26 & $<0.001$ \\
Error & 442 & 0.03 & & \\
$200 \mathrm{~m}$ & 3 & 0.01 & 1.18 & 0.315 \\
Error & 670 & 0.01 & & \\
\hline
\end{tabular}

\section{DISCUSSION}

There have been numerous reports of sea grasses, macroalgae and other plant debris aggregates in the deep sea and submarine canyons (Schoener \& Rowe 1970, Josselyn et al. 1983, Suchanek et al. 1985, Bach 1986, Alongi 1990, McHugh et al. 1992, Rice \& Lambshead 1994. Gage et al. 1995); however little is known about the ecological effects of this material. Existing evidence suggests that the presence of detrital aggregates leads to higher growth rates and/or higher abundance of benthic animals (Rowe \& Staresinic 1979, Wolff 1976, 1979, Dunton \& Schell 1987, Grassle \& MorsePorteous 1987, Duggins et al. 1989, Lawson et al. 1993, Rice \& Lambshead 1994, Snelgrove et al. 1994). Within Scripps and La Jolla Canyons the increased megafaunal abundance near detrital aggregates appeared to be due to utilization of detritus as food (urchins, holothurians) or for both food and shelter/ habitat (decapods). Infaunal abundance and biomass were significantly greater at all depths within both Scripps and La Jolla Canyons than at the non-canyon sites (Vetter \& Dayton 1998).

In addition to providing organic carbon to ocean sediments, macrophyte detritus can be exploited by metazoans either directly or following microbial processing (Fenchel \& Jørgensen 1977. Lopez et al. 1977, Levinton 1982, Kemp 1986, Peterson et al. 1986, Lopez \& Levinton 1987, Harrison 1989). It also provides habitat and/or refuge for animals (Lawson et al. 1993, Vetter 1994, 1995a). Concentration of such material within submarine canyons and relatively rapid transport of detritus to slope and bathyal depths through canyons results in ecologically important patches of ele-
Table 5. Summary of ANOVA results comparing abundance of fishes between canyon and non-canyon sites

\begin{tabular}{|lrrcc|}
\hline & df & Mean square & F-ratio & $p$ \\
\hline $500 \mathrm{~m}$ & 1 & 37.3 & 93.0 & $<0.001$ \\
Error & 1888 & 0.4 & & \\
$300 \mathrm{~m}$ & 1 & 5.9 & 31.1 & $<0.001$ \\
Error & 442 & 0.2 & & \\
$200 \mathrm{~m}$ & 3 & 13363.5 & 52.4 & $<0.001$ \\
Error & 670 & 255.2 & & \\
$100 \mathrm{~m}$ & 1 & 2113.0 & 276.8 & $<0.001$ \\
Error & 900 & 7.6 & & \\
\hline
\end{tabular}

vated benthic production (Vetter 1995b), and possibly elevated fisheries production (Stefanescu et al. 1994, Vetter \& Dayton unpubl. data). Globally, the overall importance of macrophyte detritus to the metabolism of the benthos may be small (Menzies et al. 1967, Menzies \& Rowe 1969, Schoener \& Rowe 1970); however locally important enhanced benthic production can occur in regions likely to accumulate macro-detritus, such as some submarine canyons (Josselyn et al. 1983, Gage et al. 1995, Vetter 1995a, Okey 1997. Harrold

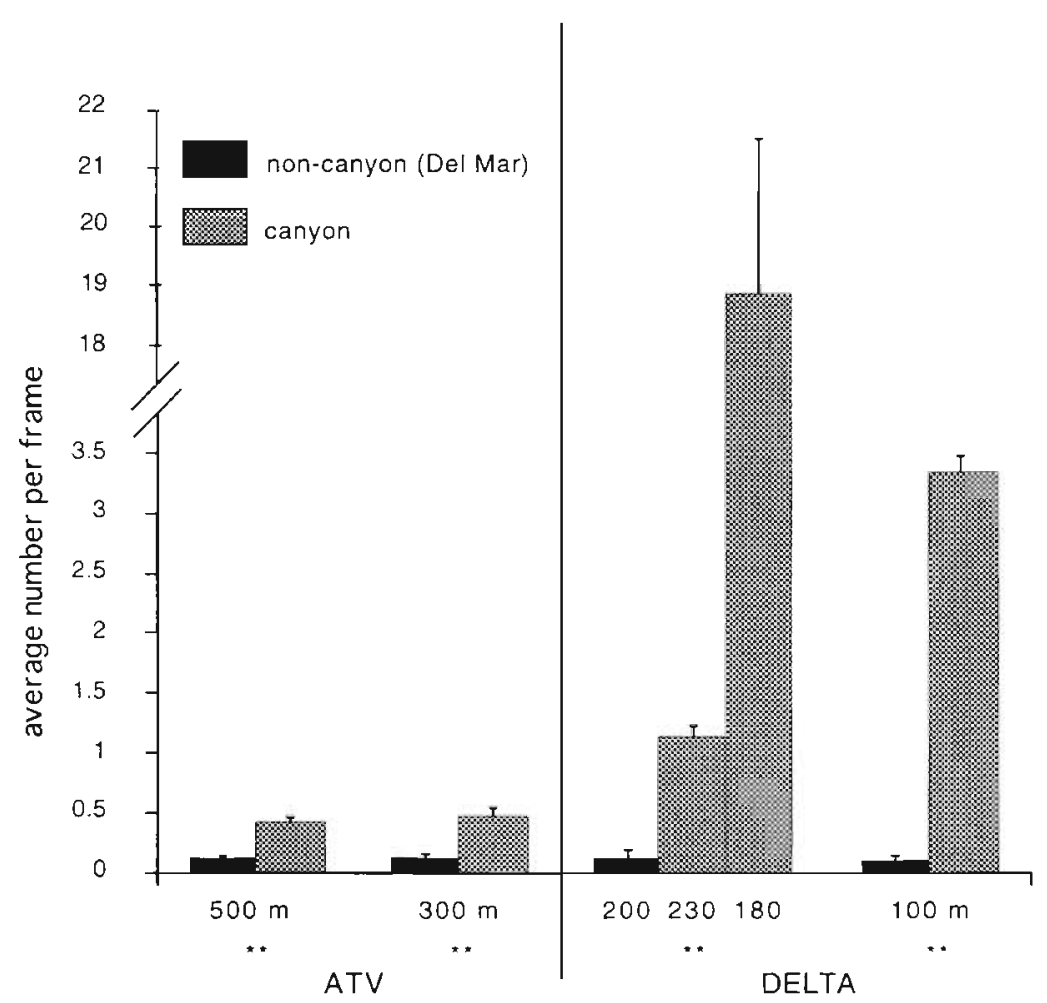

Fig. 5. Relative abundance of fishes at non-canyon (solid columns) and canyon (shaded columns) stations. Frame size approximately $1 \mathrm{~m}^{2}$ with Delta, and $2 \mathrm{~m}^{2}$ with video from ATV. Note change in scale. Error bars are 1 standard error. Asterisks indicate significant differences in fish abundances within the given depth range, $" p<0.001$ (ANOVA, Table 5) 
1998). In the absence of canyons the only major pathway for the delivery of giant kelp to great depths is the diffuse sinking of kelp paddies (Smith 1983).

The near absence of detritus at $700 \mathrm{~m}$ ( $0.2 \%$ cover) may have been primarily a result of decreased delivery of material to that depth; however, rapid consumption of macro-algal detritus by urchins probably also played a role. Nearly all fresh Macrocystis pyrifera fronds and stipes observed on the sea floor were covered by urchins. If most detritus is delivered to the deep portions of the canyons following winter and spring storms (see Josselyn et al. 1983, Vetter 1995a), much of the drift kelp transported to our study sites would have been consumed prior to our cruises in August. At $900 \mathrm{~m}$ in La Jolla Canyon we did find a kelp holdfast, but the sediments were muddy (Vetter \& Dayton 1998) suggesting that the strong currents responsible for transporting material down the canyons might be rare at this depth. Moore (1965), however, found a channel at $900 \mathrm{~m}$ in La Jolla Canyon which may have been formed by turbidity currents, suggesting that physical disturbance is periodically important in the canyon at all depths.

In an investigation of benthic detrital abundance in and around Carmel Canyon (central California) Harrold et al. (1998) also found large amounts of detritus on the canyon floor, and essentially none on the continental shelf and slope away from the canyon. Large mats of detritus (Macrocystis pyrifera, Egregia menziesii, Pterygophora californica, Gigartina spp., etc.) have been observed at $100 \mathrm{~m}$ in an offshore canyon near Pt. Conception (California), and detritus was seen moving down a second nearby canyon (BBA \& ROS 1986). Dume Canyon in northern Santa Monica Bay (Southern California) contained large accumulations of $M$. pyrifera holdfasts and surfgrass blades, which were absent at a nearby control site (Vetter \& Dayton unpubl. data). It is clear that canyons near kelp forests are important sites of drift algal and surfgrass accumulation along the California coast.

The distribution of total megabenthos in and out of the canyon did not present a clear pattern; however, when urchins are removed from the analysis, megafauna were significantly more abundant in the canyon at all depths examined (Figs. 3 \& 4). Urchins were relatively rare in the canyon in contrast to recent observations in Dume Submarine Canyon where enormous numbers of urchins (especially the urchins Allocentrotus fragilis and Strongylocentrotus purpuratus) were observed from 100 to $350 \mathrm{~m}$ in July 1996 (Vetter \& Dayton unpubl. data). This difference may be due to the disturbance regimes in the 2 canyons. Judging by fine sediment accumulation on beer and soft-drink cans (with recent designs), and large amounts of rubbish observed there, Dume Canyon has a more benign physical environment than Scripps and La Jolla Canyons. Intense tidal currents, turbidity currents and detrital flows within the Scripps-La Jolla canyon system (Inman et al. 1976) may be unfavorable to invertebrate megafauna, especially urchins. Ross (1968) made the same suggestion based on observations of abundant fishes but sparse sessile invertebrates and rapid currents within Corsair Canyon (USA east coast). Rowe (1972) theorized that high incidence of disturbance by sediment movements in the canyon would favor more motile species. This is consistent with our observations of fewer urchins, animals that may be relatively susceptible to disturbance, and more octopuses and crabs in the canyons (Table 3, Figs, 3 \& 4).

Our estimates of megafaunal (fish and invertebrates) abundance were biased downwards by our inability to effectively count animals in and under detrital aggregates. Some species, including the zoarcid Eucryphycus californica, were only found in clumps of detritus taken with the submersibles' manipulator. These fishes were surprisingly abundant in some samples (up to 5 fish in about $1 \mathrm{l}$ of detritus), and have been reported in large numbers from detrital aggregates in Monterey Submarine Canyon (Cailliet \& Lea 1977). Because of their cryptic habit, none of these fishes were recorded from the video data. Crabs Glyptolithodes cristatipes were frequently seen under patches of detritus when wash from the submersibles' thrusters disturbed the detritus; however, this only occurred while the vehicle was stopped to collect physical samples, so those observations were not included in our video transect data. One of the few instances when the presence of $G$. critatipes was recorded in our megafauna data was mentioned above for 7 large crabs grazing on a log.

Megafaunal invertebrates (especially echinoderms and decapods) in La Merenguera Canyon (western Mediterranean) were found at higher density and biomass than at nearby non-canyon stations (Cartes et al. 1994, Sardà et al. 1994). Species richness was also higher in the canyon and was presumed to stem from greater variability in physical factors such as sedimentation, currents, and supply of organic matter (Cartes et al. 1994). In a study of the community structure of continental slope epibenthic populations south of New England, Haedrich et al. (1975) reported greater trawl catch rates in the canyon $\left(228\right.$ specimens $\mathrm{h}^{-1}$ and $3.4 \mathrm{~kg}$ $\mathrm{h}^{-1}$ at slope stations, versus 368 specimens $\mathrm{h}^{-1}$ and $5.7 \mathrm{~kg} \mathrm{~h}^{-1}$ at canyon stations. Hecker et al. (1988) found that megafaunal densities were higher in Hendrickson and Lydonia Canyons than at comparable depths on the surrounding shelf and slope. High densities of filter feeders (anemones, corals and sponges) appeared to benefit from the greater availability of hard substrate and the enhanced currents within the canyons 
Increased abundance of fishes in canyons have also been observed in other studies. Stefanescu et al. (1994) found similar species of fishes in and out of a canyon (350 to $650 \mathrm{~m}$, Catalan Sea, northwestern Mediterranean), but much higher abundance and biomass in the canyon. The fishes were slightly smaller in the canyon, and the size distributions of common species led to the conclusion that the canyon acts as a nursery ground for some species. This may well be the case for juvenile Pacific hake within southern Californian submarine canyons. In an ongoing investigation, large numbers of juvenile hake were also observed in Carlsbad and Redondo Canyons (southern California) in July 1996 (Vetter unpubl. data). Stefanescu et al. (1994) surmised, as do we, that the increased abundance of fishes in the canyons is at least partially due to higher food availability there. It is also likely that physical structures such as rock walls, boulders and detritus patches in the canyon are attractive to fishes. Hecker et al. (1988) did not find any clear pattern of abundance for fishes in and out of canyons, but did consider the grenadier Coryphaenoides rupestris to be a canyon indicator species on the mid-and north-Atlantic coast of the USA. In the present study fishes that were relatively common in the canyons and rare or absent on the shelf and slope included turbot Pleuronichthys sp., the zoarcid Lycodes pacifica and juvenile hake Merluccius productus (Table 3).

The greater abundance of the benthic siphonophore Dromalia alexandri in the canyon may be related to canyon effects on currents. This species and other rhodaliid siphonophores, such as Thermopalia taraxaca, the 'dandelion' described from the 'Rose Garden' hydrothermal vent in the Galápagos Rift region (Pugh 1983), are buoyed up by a large pneumatophore, and are typically found anchored to the sea floor with their tentacles. This arrangement allows the animals to benefit from currents flowing past their feeding zooids without having to grow out of, or even having significant structures in the benthic boundary layer. We observed a $D$. alexandri float slowly to the bottom and anchor itself in the canyon, so these animals appear to have some influence over where they will reside. If they behave like 'optimal foragers', it is reasonable to presume that they will remain longer in places with high food density or where currents are strong enough to increase the flux of food past their gastrozooids, without being so strong that they cause the animals to loose their purchase on the substrate. $T$. taraxaca is found in abundance on the periphery of some hydrothermal vents (Galápagos, $13^{\circ} \mathrm{N}$ East Pacific Rise) (Hessler \& Smithey 1983, Tunnicliffe 1991) where, in addition to high particle concentrations in the water, convective water motion generated by the vent fields should result in current speeds elevated above background levels (Enright et al. 1981); however $T$. taraxaca is also very common in some regions of the southern East Pacific Rise away from vents $(C$. van Dover pers. comm.). The relatively high abundance of $D$. alexandri in the canyon may reflect a preference for regions with relatively strong currents. Several studies have reported enhanced current flows in submarine canyons (Shepard et al. 1964, 1979, Shepard \& Marshall 1973, Gordon \& Marshall 1976. Inman et al. 1976) which may result from along-shore pile up of water by strong onshore winds, downcanyon pulses resulting from high incident waves, standing waves producing down-canyon oscillations, or turbidity currents (Inman et al. 1976). Tidal flows, internal waves, and spin-off eddies from large current systems are more likely to drive canyon currents in deep-water (also see Freeland \& Denman 1982, Noble \& Butman 1989, Durrieu De Madron 1994, Alvarez et al. 1996).

\section{CONCLUSIONS}

It is clear that physical conditions in canyons are often distinct from the surrounding shelf and slope, and can affect the structure of canyon communities We feel the following generalizations are warranted:

(1) Submarine canyons in the vicinity of populations of macroalgae or surfgrass receive extensive inputs of macrophyte detritus and will probably be organically enriched by that material.

(2) Organic enrichment in canyons may lead to greater than background densities of megafaunal invertebrates; however, even in canyons where detritus is abundant, some megafauna such as echinoderms may actually be present at lower than background density because of higher disturbance rates in canyons.

(3) Detrital patches attract megafauna and on small scales their density is enhanced in the immediate vicinity of organic aggregates.

(4) Fish abundance is enhanced in canyons, and canyons may serve as important nursery grounds for fishes; explanations may include increased availability of benthic or planktonic prey and the increased structural diversity found in canyons.

When compared to regions on the surrounding continental shelf and slope, submarine canyons are responsible for substantial accumulation of organic material. Canyons provide conduits for the rapid transport and deposition of macroalgal and seagrass detritus to great depths. In the absence of canyons much of the macro-detritus would be consumed or simply buried on the shallow portions of the shelf. 
Acknowledgements. We thank D. Cadien and R. Rosenblatt for help with megafaunal identifications. We are grateful to $P$. Brueggeman, A. Dayton, P. Dixon, R. Hessler, A. Hobday, C. Jones, L. Levin, C. Liang, A. MCCray, E. Nestler, S. Rumsey, M. Sigala, T Talley, D. Stokes, D. Talley, M. Tegner and P. Vetter for laboratory and shipboard assistance. This manuscript was improved by reviews provided by P. Brueggeman, L. Levin, M. Tegner and 3 anonymous reviewers. The success of this work was made possible by the skill, long hours and good humor of the crews of the 'Laney Chouest', 'Cavalier', 'Sea Cliff', 'Delta' and ATV. This work was supported by a grant from the West Coast Center of the National Undersea Research Program (NOAA) and the Hawaii Pacific University Trustees Scholarly Endeavors fund

\section{LITERATURE CITED}

Alongi DM (1990) Bacterial growth rates, production and estimates of detrital carbon utilization in deep-sea sediments of the Solomon and Coral Seas. Deep-Sea Res $37: 731-746$

Alvarez A, Tintoré J, Sabatés A (1996) Flow modification and shelf-slope exchange induced by a submarine canyon off the northeast Spanish coast. J Geophys Res 101 12043-12055

Bach SD, Thayer GW, LaCroix MW (1986) Export of detritus from eelgrass (Zostera marina) beds near Beaufort, North Carolina, USA. Mar Ecol Prog Ser 28:265-278

BBA \& ROS (1986) Biological survey of the 'PROTEUS' lease OCSP-0512 offshore Point Conception, California. Prepared by Benech Biological and Associates, Ventura, CA, and Remote Ocean System, Inc, San Diego, CA

Billett DSM, Lampitt RS, Rice AL, Mantoura RFC (1983) Seasonal sedimentation of phytodetritus to the deep-sea benthos. Nature 302:520-522

Cailliet GM, RN Lea (1977) Abundance of the 'rare' zoarcid, Maynea californica Gilbert, 1915, in the Monterey canyon, Monterey Bay, California. Calif Fish Game 63:253-261

Cartes JE, Sardà F, Company JB, Lleonart J (1993) Day-night migrations by deep-sea decapod crustaceans in experimental samplings in the western Mediterranean Sea. J Exp Mar Biol Ecol 171:63-73

Cartes JE, Company JB, Maynou F (1994) Deep-water decapod crustacean communities in the northwestern Mediterranean: influence of submarine canyons and season. Mar Biol 120:221-229

Duggins DO, Simenstad CA, Estes JA (1989) Magnification of secondary production by kelp detritus in coastal marine ecosystems. Science 245:170-173

Dunton KH, Schell DM (1987) Dependence of consumers on macroalgal (Laminaria solidungula) carbon in an arctic kelp community: $\delta^{13} \mathrm{C}$ evidence. Mar Biol 93:615-625

Durrieu De Madron X (1994) Hydrography and nepheloid structures in the Grand-Rhóne Canyon. Cont Shelf Res 14 : $457-477$

Enright JT, Newman WA, Hessler RR, McGowan JA (1981) Deep-ocean hydrotbermal vent communities. Nature 289 : $219-221$

Fenchel TM, Jørgensen BB (1977) Detritus food chains of aquatic ecosystems: the role of bacteria. In: Alexander $M$ (ed) Advances in microbial ecology. Plenum Press, New York, $\mathrm{p}$ 1-58

Foster MS, Schiel DR (1985) The ecology of giant kelp forests in California: a community profile. US Fish Wild Serv Biol Rep 85(7.2)

Freeland HJ, Denman KL (1982) A topographically induced upwelling center off southern Vancouver Island. J Mar Res 40:1069-1093

Gage JD, Lamont PA, Tyler PA (1995) Deep-sea macrobenthic communities at contrasting sites off Portugal, preliminary results. I. Introduction and diversity comparisons. Int Rev Ges Hydrobiol 80:235-250

Gardner WD (1989) Baltimore Canyon as a modern conduit of sediment to the deep sea. Deep-Sea Res 36:323-358

Gerard VA (1976) Some aspects of material dynamics and energy flow in a kelp forest in Monterey Bay, California. PhD thesis, University of California, Santa Cruz

Gordon RL, Marshall NF (1976) Submarine canyons: internal wave traps? Geophys Res Lett 3:622-624

Grassle JF, Morse-Porteous LS (1987) Macrofaunal colonization of disturbed deep-sea benthic communities. DeepSea Res 34:1911-1950

Greene $\mathrm{CH}$, Weibe $\mathrm{PH}$, Burczynski J, Youngbluth MJ (1988) Acoustical detection of high-density demersal krill layers in the submarine canyons off Georges Bank. Science 241: $359-361$

Haedrich RL, Rowe GT, Polloni PT (1975) Zonation and faunal composition of epibenthic populations on the continental slope south of New England. J Mar Res 33:191-212

Haedrich RL, Rowe GT, Polloni PT (1980) The megabenthic fauna of the deep sea south of New England, USA. Mar Biol 57:165-179

Harrison PG (1989) Detrital processing in seagrass systems: a review of factors affecting decay rates. Remineralization and detritivory. Aquat Bot 23:263-288

Harrold C, Light K, Lisin S (1998) Organic enrichment of continental shelf and deep-sea benthic communities by macroalgal drift imported from nearshore kelp forests. Limnol Oceanogr 43:669-678

Hecker B, Logan DT, Gandarillas FE, Gibson PR (1988) Canyon and slope processes study, IIl. Biological processes. Lamont-Doherty Geological Observatory, Columbia University, New York

Hessler RR, Smithey WM Jr (1983) The distribution and community structure of megafauna at the Galápagos Rift hydrothermal vents. In: Rona PA, Bonström K, Laubier L, Smith KL Jr (eds) Hydrothermal processes at seafloor spreading centers. NATO Conference Series IV. Plenum Press, New York, p 735-770

Houston KA, Haedrich RL (1984) Abundance and biomass of macrobenthos in the vicinity of Carson Submarine Canyon, northwest Atlantic Ocean. Mar Biol 82:301-305

Inman DL, Brush BM (1973) The coastal challenge. Science $81: 20-32$

Inman DL, Frautschy JD (1965) Littoral processes and the development of shorelines. In: Coastal engineering (Santa Barbara Specialty Conf). Am Soc Civil Eng, New York

Inman DL, Nordstrom CE, Flick RE (1976) Currents in submarine canyons: an air-sea-land interaction. Annu Rev Fluid Mech 8:275-310

Josselyn MN, Cailliet GM, Niesen TM, Cowen R, Hurley AC, Connor J, Hawes S (1983) Composition, export and faunal utilization of drift vegetation in the Salt River submarine canyon. Estuar Coast Shelf Sci 17:447-465

Kemp PF (1986) Direct uptake of detrital carbon by the deposit-feeding polychaete Euzonus mucronata (Treadwell). J Exp Mar Biol Ecol 99:49-61

Koslow JA, Ota A (1981) The ecology of vertical migration in three common zooplankters in the La Jolla Bight. AprilAugust 1967. Biol Oceanogr 1:107-134

Lampitt RS (1985) Evidence for the seasonal deposition of detritus to the deep-sea floor and its subsequent resuspension. Deep-Sea Res 32:885-897 
Lawson G, Tyler PA, Young CM (1993) Attraction of deep-sea amphipods to macrophyte food falls. J Exp Mar Biol Ecol $169: 33-39$

Levinton JS (1982) Marine ecology. Prentice-Hall Inc, Englewood Cliffs, NJ

Lopez GR, Levinton JS, Slobodkin LB (1977) The effect of grazing by the detritivore Orchestia grillus on Spartina litter and its associated microbial community. Oecologia 30 $111-127$

Lopez GR, Levinton JS (1987) Ecology of deposit-feeding animals in marine sediments. Q Rev Biol 62:235-260

Macquart-Moulin C, Patriti G (1993) Canyons sous-marins et advection vers le talus continental du plancton néritique. Oceanol Acta 16:179-189

Maurer D, Robertson G, Gerlinger T (1994) Comparisons of community structure of soft-bottom macrobenthos of the Newport Submarine Canyon, California, and the adjoining shelf. Int Rev Ges Hydrbiol 79:591-603

McHugh CM, Ryan WBF, Hecker B (1992) Contemporary sedimentary processes in the Monterey Canyon-fan system. Mar Geol 107:35-50

Menzies RJ, Zaneveld JS, Pratt RM (1967) Transported turtle grass as a source of organic enrichment of abyssal sediments off North Carolina. Deep-Sea Res 14:111-112

Menzies RJ, Rowe GT (1969) The distribution and Significance of detrital turtle grass, Thallassia testudinata, on the deep-sea floor off North Carolina. Int Rev Ges Hydrobiol $54: 217-222$

Moore DG (1965) The erosional channel wall in La Jolla seafan valley seen from bathyscaph TRIESTE. Bull Geol Soc Amer 76:385-392

Noble M, Butman B (1989) The structure of subtidal currents within and around Lydonia Canyon: evidence for enhanced cross-shelf fluctuations over the mouth of the canyon. J Geophys Res 94:8091-8110

Okey TA (1993) Natural disturbances and benthic communities in Monterey Canyon head. Masters thesis, San Jose State University, San Jose, CA

Okey TA (1997) Sediment hushing observations, earthquake slumping, and benthic community changes in Monterey Canyon head. Contin Shelf Res 17:877-897

Peterson BJ, Howarth RW, Garritt RH (1986) Sulfur and carbon isotopes as tracers of salt-marsh organic matter flow. Ecology 67:865-874

Pugh PR (1983) Benthic siphonophores: a review of the family Rhodaliidae (Siphonophora, Physonectae). Philos Trans R Soc Lond B 301:165-300

Rice L, Lambshead PJD (1994) Patch dynamics in the deepsea benthos: the role of a heterogeneous supply of organic matter. In: Giller PS, Hildrew AG, Raffaelli DG (eds) Aquatic ecology: scale, pattern and process. Blackwell Scientific, London, p 469-497

Ross DA (1968) Current action in a submarine canyon. Nature $218: 1242-1244$

Rowe GT (1971) Observations on bottom currents and epibenthic populations in Hatteras submarine canyon. Deep-Sea Res 18:569-581

Rowe GT (1972) The exploration of submarine canyons and their benthic faunal assemblages. Proc R Soc Edinb Sect B $73: 159-169$

Rowe GT, Staresinic N (1979) Sources of organic matter to the deep-sea benthos. Special Report No. 6, The deep seaecology and exploitation. Ambio 6:19-23

Rowe GT, Polloni PT, Haedrich RL (1982) The deep-sea macrobenthos on the continental margin of the northwest Atlantic Ocean. Deep-Sea Res 29:257-278

Sardà F, Cartes JE, Company JB (1994) Spatio-temporal vari- ations in megabenthos abundance in three different habitats of the Catalan deep-sea (western Mediterranean). Mar Biol 120:211-219

Schoener A, Rowe GT (1970) Pelagic Sargassum and its presence among the deep-sea benthos. Deep-Sea Res 17: 923-925

Shepard FP (1973) Submarine geology, 3rd edn. Harper \& Row, New York

Shepard FP, Dill RF (1966) Submarine canyons and other sea valleys. Rand McNally \& Co. Chicago

Shepard FP, Marshall NF (1973) Currents along floors of submarine canyons. Am Assoc Pet Geol Bull 57:244-264

Shepard FP, Curray JR, Inman DL, Murray EA, Winterer EL, Dill RF (1964) Submarine geology by diving saucer. Science 145:1042-1046

Shepard FP, Marshall NF, McLoughlin PA, Sullivan GG (1979) Currents in submarine canyons and other sea valleys. AAPG studies in geology. Vol. 8. American Association of Petroleum Geologists, Tulsa

Smith CR (1983) Enrichment, disturbance and deep-sea community structure: the significance of large organic falls to bathyal benthos in Santa Catalina Basin. PhD thesis, University of California, San Diego

Smith CR (1985) Food for the deep sea: utilization, dispersal, and flux of nekton falls at the Santa Catalina Basin floor. Deep-Sea Res 32:417-442

Smith CR (1986) Nekton falls, low-intensity disturbance and community structure of infaunal benthos in the deep sea. J Mar Res 44:567-600

Smith KL Jr, Baldwin RJ, Williams PM (1992) Reconciling particulate organic carbon flux and sediment community oxygen consumption in the deep North Pacific. Nature 359: $313-316$

Snelgrove PVR, Grassle JF, Petrecca RF (1994) Macrofaunal response to artificial enrichments and depressions in a deep-sea habitat. J Mar Res 52:345-369

Stefanescu C, Morales-Nin B, Massuti E (1994) Fish assemblages on the slope in the Catalan Sea (western Mediterranean): influence of a submarine canyon. J Mar Biol Assoc UK 74:499-512

Stockton WL, DeLaca TE (1982) Food falls in the deep sea: occurrence, quality, and significance. Deep-Sea Res 29: $157-169$

Suchanek TH, Williams SL, Ogden JC, Hubbard DK, Gill IP (1985) Utilization of shallow-water seagrass detritus by Caribbean deep-sea macrofauna: $\delta^{13} \mathrm{C}$ evidence. DeepSea Res 32:201-214

Thiel $\mathrm{H}$, Pfannkuche $\mathrm{O}$, Schriever S, Lochte $\mathrm{K}$, Gooday AJ, Hemleben $\mathrm{CH}$, Mantoura RFG, Turley CM, Patching JW, Riemann F (1988/1989) Phytodetritus on the deep-sea floor in a central oceanic region of the Northeast Atlantic. Biol Oceanogr 6:203-239

Thrush SF (1986) The sublittoral macrobenthic community structure of an Irish sea-lough: effect of decomposing accumulations of seaweed. J Exp Mar Biol Ecol 96 $199-212$

Tunnicliffe $V$ (1991) The biology of hydrothermal vents: ecology and evolution. Oceanogr Mar Biol Annu Rev 29:319-407

VanBlaricom GR (1982) Experimental analyses of structural regulation in a marine sand community exposed to oceanic swell. Ecol Monogr 52:283-305

Vetter EW (1994) Hotspots of benthic production. Nature 372 47

Vetter EW (1995a) Southern California Nebalia: ecology, production, natural history and systematics of three subtidal species. PhD thesis, University of California, San Diego, p $1-243$ 
Vetter EW (1995b) Detritus-based patches of high secondary production in the nearshore benthos. Mar Ecol Prog Ser 120:251-262

Vetter EW (1996) Enrichment experiments and infaunal population cycles on a Southern California sand plain: response of the leptostracan Nebalia daytoni and other infauna. Mar Ecol Prog Ser 137:83-93

Vetter EW (1998) Population dynamics of a dense assemblage of marine detritivores J Exp Mar Biol Ecol 226: 131-161

Vetter EW, Dayton PK (1998) Macrofaunal communities

Editorial responsibility: Otto Kinne (Editor),

Oldendorf/Luhe, Germany within and adjacent to a detritus-rich submarine canyon system. Deep-Sea Res II 45:25-54

Wolff $T$ (1976) Utilization of seagrasses in the deep sea. Aquat Bot 2:161-174

Wolff $T$ (1979) Macrofaunal utilization of plant remains in the deep sea. Sarsia 64:117-136

Zobell CE (1959) Factors affecting drift seaweeds on some San Diego beaches. Institute of Marine Resources, University of California, San Diego

Zobell CE (1971) Drift seaweeds on San Diego county beaches. Nova Hedwigia 32:269-318

Submitted: September 9, 1998; Accepted: October 15, 1998 Proofs received from author(s): September 7, 1999 